\title{
Urban Sprawl and the Cost of Public Services: An Evaluation of Spanish Local Governments
}

\author{
BERnARdino BENito, FranCisco BASTIDA \& MARÍA-DOLORES GUILLAMÓN
}

\begin{abstract}
This paper evaluates the impact of urban sprawl on municipal expenditures, considering all the 3,179 Spanish municipalities with more than 1,000 inhabitants in 2005. We have ascertained that there is an influence of urban sprawl on per capita spending: the higher the population density, the lower the total investment and current expenditures per capita. This result supports the claims in favour of smart growth in municipalities. Furthermore, the economic level exerts a positive influence on expenditures per capita. Concerning social factors, our data show that population yields economies of scale to a limit (the function presents a U-shape): from the point of the minimum per-capita spending, if the population keeps on growing, per-capita spending rises.
\end{abstract}

KEYWORDS: • urban sprawl • municipal spending • public services • smart growth $\bullet$ Spain

Correspondence AdDress: Bernardino Benito, Department of Accounting, Faculty of Economics and Business, University of Murcia-Zampus of Espinardo, 30100 Espinardo (Murcia), Spain, email: benitobl@um.es. Francisco Bastida, Department of Accounting, Faculty of Economics and Business, University of Murcia-Zampus of Espinardo, 30100 Espinardo (Murcia), Spain, email: alba@um.es. María-Dolores Guillamón, Department of Accounting, Faculty of Economics and Business, University of Murcia-Zampus of Espinardo, 30100 Espinardo (Murcia), Spain, email: mdguillamon@um.es. 
During the last few years, the rapid expansion of metropolitan areas ("urban sprawl") has led to social, economic, and political debates. This pattern of land development is typical of the USA, and it is also happening in Europe, IberoAmerica, and Asia (Burchell et al., 1998).

Regarding the origin of the term "urban sprawl", there is no clear consensus in the literature. Some authors claim that it did not appear until the late 1950s. Other authors such as Hess et al. (2001) mention that it has already been used by Buttenheim and Cornick (1938), and that it became relatively popular in the 1940s and 1950s with the increase of automobile use and highway expansion. Therefore, it is not a new concept.

Something similar happens with the definition of "urban sprawl". On the one hand, some authors are hesitant to give a definition: Ewing (1997) defines sprawl as the spread-out, skipped-over development that characterises the non-central city metropolitan, and non-metropolitan areas in the United States of America. Burchell and Mukherji (2003) give another definition: low-density, leapfrog development that is characterised by unlimited outward extension. In other words, sprawl stands for "significant residential or non-residential development". In general, sprawl development means low density. Other works show that sprawl is a kind of a low-density, spatially expansive pattern of development that has become prevalent throughout the USA over the last 50 years (Glaeser and Kahn, 2004; Nechyba and Walsh, 2004; Bruegmann, 2005; Burchfield et al., 2006; Carruthers and Ulfarsson, 2008). Furthermore, Galster et al. (2001) argue that sprawl is represented by low values of one or more of the following dimensions: density, continuity, concentration, clustering, centrality, nuclearity, mixed uses, and proximity.

Despite the ambiguity of the concept, it has attracted much interest. Burchell et al. (1998) show different categories and distribution of literature on sprawl. In general, researchers have focused on an empirical analysis (census or case study), and to a lesser extent, on a descriptive and econometric analysis. The level of analysis also changes, depending on the category studied.

This paper evaluates the impact of population density on municipal expenditures. On the one hand, we try to expand the scarce research on sprawl in the European countries (most of the literature has focused on the USA). On the other hand, we contribute one of the most representative samples used so far: 3,179 Spanish local governments (LGs) to the literature.

The paper is organised as follows. Section 2 reviews the literature on urban sprawl. Section 3 provides a brief description of LGs in Spain. Section 4 includes 
a detailed description of the research design and methodology. Section 5 analyses empirical results. Finally, section 6 summarises conclusions.

\section{Literature Review on Municipal Financial Management}

\subsection{Urban Sprawl}

The empirical literature has examined the causes and consequences of sprawl, as well as its costs and benefits. This is not an easy task, and some researchers have suggested that the costs and benefits of spatial use (whether sprawl or consolidated development) are very difficult to measure (Litman, 2003; Knaap, 2003; Cox \& Utt, 2004). Carruthers and Ulfarsson (2003) believe that it is impossible for a unique analysis to account for all the relative costs and benefits of alternative development patterns. However, these authors claim the need for further research on how the physical and political dimensions of metropolitan areas affect public service expenditure. According to McGuire and Sjoquist (2002), the literature provides contradictory arguments on the suggested effects of sprawl.

Several studies indicate that per capita municipal expenditures are higher under sprawl development compared to controlled growth or "smart growth" development, which has been coined by some authors in contrast to urban sprawl. The research on the cost of sprawl by the Real Estate Research Corporation (RERC, 1974) is one of these studies. In addition, it has become the starting point for next works. However, this study has also been criticised because its methodology combines public and private expenditures. Accordingly, other authors began studying public expenditures because they sought to define the relationship between land use patterns and local government costs.

The U.S. urban planning community has stated several assumptions about suburbanisation and local government expenditures, i.e., lower spending per capita is associated with: (a) higher population density, (b) lower population growth rates, and (c) older municipalities. Cox and Utt (2004) examine whether or not these assumptions are met by a sample of 738 U.S. municipalities. They have found no significant confirmation of the three aforementioned assumptions: there must be other factors affecting local government expenditures.

The empirical results on the relationship between population density and the cost of public services are mixed. Some authors find that per capita public expenditures tend to rise as density increases (Ladd \& Yinger, 1991; Ladd, 1992; Ladd, 1994; Holcombe \& Williams, 2008). Other works show the opposite conclusion (Downing, 1969; Dajani, 1973; Carruthers \& Ulfarsson, 2003; Burchell and Mukherji, 2003; Litman, 2004; Carruthers \& Ulfarsson, 2008). Other studies find little significance (Cox \& Utt, 2004). Finally, Ladd (1992) identifies a U-shaped non-linear relationship between current expenditures and population density. 
The literature has gone further to explore the relationship between population density and infrastructure spending. Sprawl is assumed to be costly in terms of providing public infrastructure and services such as roads, garbage collection, schools, and public transport (Burchell et al., 1998). The cost of providing infrastructure and municipal services is higher with sprawl (Snyder and Bird, 1998). According to Whitney and Gordon (2001), several studies have shown that local governments spend more money when providing public services to communities in suburbs. Livingstone et al. (2003) indicate the reasons why sprawl development requires more expensive investments compared to smart growth. In general, the literature shows that the impact of higher population density on infrastructure costs depends on the type of the infrastructure at stake.

Economies of scale are the main reasons why the literature indicates the justification of the cost savings stemming from population density. Shapiro (1963) concludes that economies of scale yield a U-shaped function of some infrastructure expenditures. 250,000 inhabitants are the point where the curve gets a positive slope. Schmandt and Stephens (1963) show the same conclusion as Shapiro, but they find that the critical population is 50,000 instead of 250,000 . Burchell (1992) indicates that the concentration of people in more compact areas produces economies of scale: this could reduce the water and sewer cost per capita. Carruthers and Ulfarsson (2008) argue that sprawl does not take advantage of economies of scale, and therefore does not reduce several public costs such as public education, public transport or police. Both Tiebout (1960) and Carruthers and Ulfarsson (2008) indicate that not only the cost effectiveness of public services is important, but also the quality of the services provided.

The relationship between public expenditures and sprawl has implications for the policy-making process. In this way, local governments should promote more beneficial and cost-efficient fiscal and land use policies, thereby taking into account other relevant factors. Knaap et al. (2000) conclude that although government policies have a significant influence on urban sprawl, this development is not the result of government policies alone. They also specify that some policies are more influential on urban sprawl than others are. The most important factors affecting sprawl are: transport costs, new housing prices on urban outskirts, the financial structure of local governments, and the new infrastructure extension. According to McElfish (2007), sprawl stems from inadequate laws and incorrect government policies that have led to a wrong urban development pattern.

Regarding smart growth, Litman (2004) defines this concept as more compact and accessible urban development. In fact, one of the claimed benefits of smart growth is a reduction in transport, development, and public service costs. Burchell et al. (2000) study the smart growth implications: control of outward movement, inner- 
area revitalisation and growth in places that are more central, design innovations, land preservation, natural resource conservation, and reorientation of transport.

Fabricant (1952) included population density in order to explain local government fiscal behaviour. Borge (1995) takes into account the population density to control for structural differences in the financial situation of local governments. Bails and Tieslau (2000) ascertain that population density can be related to the level of state and local government spending.

On the one hand, a dense population may increase the marginal benefits of spending if it creates unique public goods problems: this means a positive relationship between density and per capita expenditure (Ladd 1992 perceived this positive relationship).

On the other hand, population density may lead to economies of scale in the local government service provision. In this case, we expect a negative relationship between these two variables. However, some authors indicate that once the municipal population grows beyond its capacity, economies of scale disappear and thus per capita expenditure increases. Table 1 summarises the most relevant recent literature on urban sprawl.

Table 1: Literature on relationship between spending and urban sprawl

\begin{tabular}{|c|c|c|c|c|}
\hline Study & Sample & Dependent variables & Independent variables & Results \\
\hline 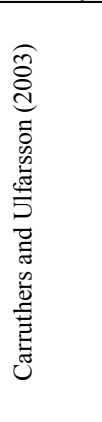 & $\begin{array}{c}283 \\
\text { metropolitan } \\
\text { counties } \\
\text { US States } \\
(1982-1992)\end{array}$ & $\begin{array}{l}\text {-Per capita total } \\
\text { expenditure } \\
\text {-Per capita spending: } \\
\text { capital facilities, } \\
\text { roadways, other } \\
\text { transportation, } \\
\text { sewerage, trash } \\
\text { collection, housing, } \\
\text { police protection, parks, } \\
\text { education, libraries }\end{array}$ & $\begin{array}{l}\text {-Built environment: } \\
\text { density, urbanized land, } \\
\text { property value } \\
\text {-Political } \\
\text { characteristics: per } \\
\text { capita municipal } \\
\text { governments, per capita } \\
\text { special districts, central } \\
\text { city indicator } \\
\text {-Revenue: per capita } \\
\text { local tax revenue, per } \\
\text { capita } \\
\text { intergovernmental } \\
\text { revenue }\end{array}$ & $\begin{array}{l}\text { Density is negative } \\
\text { and significant } \\
(0.10) \text { in overall } \\
\text { public spending, } \\
\text { capital facilities, } \\
\text { roadways, police } \\
\text { protection, and } \\
\text { education } \\
\text { Density is positive } \\
\text { and insignificant in } \\
\text { sewerage }\end{array}$ \\
\hline
\end{tabular}




\begin{tabular}{|c|c|c|c|c|}
\hline 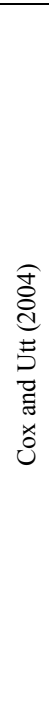 & $\begin{array}{c}738 \\
\text { municipalities } \\
\text { US States } \\
(1990-2000)\end{array}$ & $\begin{array}{l}\text {-Per capita total } \\
\text { expenditure } \\
\text { - Per capita spending: } \\
\text { Wastewater charges } \\
\text { Water charges }\end{array}$ & $\begin{array}{l}\text {-Percentage of } \\
\text { population below the } \\
\text { poverty line } \\
\text {-Population in } 2000 \\
\text {-Median age of owner- } \\
\text { occupied housing } \\
\text {-Ratio of local to state } \\
\text { and local direct } \\
\text { government } \\
\text { expenditures } \\
\text {-Total aid per capita } \\
\text {-Population density } \\
\text {-percentage of } \\
\text { population change } \\
\text { between } 1990 \text { and } 2000 \\
\text {-Persons per household } \\
\text {-percentage of owner- } \\
\text { occupied housing } \\
\text {-Median house value } \\
\text {-Percentage of } \\
\text { population over } 65 \\
\text {-Land area (square } \\
\text { miles) } \\
\text {-Crime rate per capita }\end{array}$ & $\begin{array}{l}\text { Significant factors : } \\
\text { - poverty rate } \\
\text { - local/state } \\
\text { expenditure ratio } \\
\text { - state and federal } \\
\text { aid } \\
\text { - density (negative) } \\
\text { - persons per } \\
\text { household } \\
\text { - owner-occupied } \\
\text { housing } \\
\text { - median house value } \\
\text { crime rate } \\
\text { Lowest expenditures } \\
\text { per capita tend to be } \\
\text { in medium- and } \\
\text { lower-density } \\
\text { municipalities } \\
\text { (though not the } \\
\text { lowest density). }\end{array}$ \\
\hline 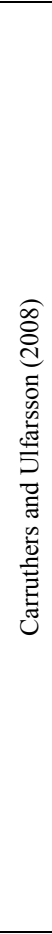 & $\begin{array}{c}3,075 \text { counties } \\
\text { US States } \\
(2001-2002)\end{array}$ & $\begin{array}{l}\text {-Per capita total direct } \\
\text { expenditures } \\
\text {-Per capita spending: } \\
\text { Education } \\
\text { Fire protection } \\
\text { Housing and } \\
\text { Community } \\
\text { Development } \\
\text { Libraries } \\
\text { Parks and Recreation } \\
\text { Police Protection } \\
\text { Roadways } \\
\text { Sewerage } \\
\text { Solid Waste } \\
\text { Management }\end{array}$ & $\begin{array}{l}\text {-Built Environment: } \\
\text { density, percentage of } \\
\text { land area developed, } \\
\text { median housing value, } \\
\text { percentage of housing } \\
\text { built before } 1940 \\
\text {-Political Structure: per } \\
\text { capita municipal } \\
\text { governments, per capita } \\
\text { special districts } \\
\text {-Growth and } \\
\text { Demographics: rate of } \\
\text { population change, per } \\
\text { capita income, } \\
\text { percentage of white } \\
\text { population, percentage } \\
\text { of population under } 5 \\
\text { years of age, average } \\
\text { household size } \\
\text {-Sources of Revenue: } \\
\text { per capita federal } \\
\text { revenue, per capita state } \\
\text { revenue, per capita tax } \\
\text { revenue, percentage of } \\
\text { tax revenue from } \\
\text { property taxes, per } \\
\text { capita long-term debt } \\
\text {-Size and Primacy: } \\
\text { county size, } \\
\text { employment-to- } \\
\text { population ratio }\end{array}$ & $\begin{array}{l}\text { Density: } \\
\text { Negative sign and } \\
\text { statistically } \\
\text { significant in the } \\
\text { total direct, } \\
\text { education, roadways, } \\
\text { and sewerage } \\
\text { models } \\
\text { Positive sign and } \\
\text { statistically } \\
\text { significant in } \\
\text { housing and } \\
\text { community } \\
\text { development }\end{array}$ \\
\hline
\end{tabular}




\begin{tabular}{|c|c|c|c|c|}
\hline 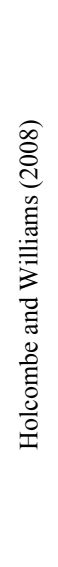 & $\begin{array}{c}487 \\
\text { municipalities } \\
\text { US States } \\
(1990-2000)\end{array}$ & $\begin{array}{l}\text {-Per capita total } \\
\text { expenditures } \\
\text {-Per capita current } \\
\text { operating expenditures } \\
\text {-Per capita spending: } \\
\text { Highways } \\
\text { Water } \\
\text { Sewer } \\
\text { Police } \\
\text { Fire }\end{array}$ & $\begin{array}{l}\text {-Population in } 2000 \\
\text {-density } \\
\text {-average commuting } \\
\text { times } \\
\text {-population growth from } \\
1990 \text { to } 2000 \\
\text {-percentage of } \\
\text { population attending } \\
\text { college } \\
\text {-labour force } \\
\text { participation rate } \\
\text {-poverty rate } \\
\text {-median home } \\
\text {-median age } \\
\text {-median income } \\
\text {-state } \\
\text {-percentage of } \\
\text { population attending } \\
\text { school }\end{array}$ & $\begin{array}{l}\text { Positive and } \\
\text { significant } \\
\text { relationship between } \\
\text { density and per } \\
\text { capita expenditures } \\
\text { for cities with a } \\
\text { population over } \\
500,000 \text { and no } \\
\text { significant } \\
\text { relationship between } \\
\text { density and total or } \\
\text { operating } \\
\text { expenditures for } \\
\text { smaller cities. }\end{array}$ \\
\hline
\end{tabular}

\subsection{Social and Economic Factors}

\section{Population}

Since the early work of Fabricant (1952), urbanisation (proportion of citizens living in urban areas) has become a "classical variable" in explaining local government fiscal behaviour. Furthermore, the classic theory of public finance shows that urbanisation determines government growth in municipalities. The explanation of this long-standing theory, known as Wagner's Law, is the pressure for social progress and the resulting changes in the relative proportions of private and public economy (Wagner, 1958).

Hempel (1973), Hulten and Peterson (1984), and Rivers and Yates (1997) argue theoretically that population growth causes an increased requirement for municipal expenditures. Farnham (1985) has empirically verified the same relationship. According to Groves et al. (1981), population influences the municipal financial situation. Large local governments receive higher demands for public expenditures from their citizens (Ashworth et al., 2005). Bird (1970) points out that government spending expansion is caused, among other factors, by population growth, urbanisation, and development. Thus, Borge (1995) and Pettersson-Lidbom (2001), in their econometric analysis, control for the influence of population on local governments financial situation.

Following the traditional literature on sprawl, population size and growth are widely accepted variables in order to explain the effects of unregulated development on public expenditure. Bodkin and Conklin (1971) suggest that the relationship between population size and expenditures varies from one expenditure category to another. Ladd (1992) shows that higher population growth is associated with lower per capita local government expenditures. Carruthers and 
Ulfarsson (2008) find a negative relationship between population change and total direct expenditures and other expenditures such as education, housing and community development, parks and recreation, police protection, and solid waste management. Cox and Utt (2004) show no significant relationship between higher population growth and higher municipal expenditures per capita. Holcombe and Williams (2008) indicate that higher population growth is not associated with higher per capita total expenditures or per capita current operating expenditures. However, they find that higher population growth is associated with higher per capita highway expenditures and with lower per capita water expenditures.

Schmandt and Stephens (1963) show that both very large and very small local governments suffer from diseconomies of scale. Thus, their data indicate a Ushaped trend. Figure 1 shows a similar pattern for the Spanish local governments of our sample: they benefit from economies of scale as the population rises up to a limit because the slope becomes positive from that limit.

\section{Figure 1: Population and total expenditure per capita in the sample}

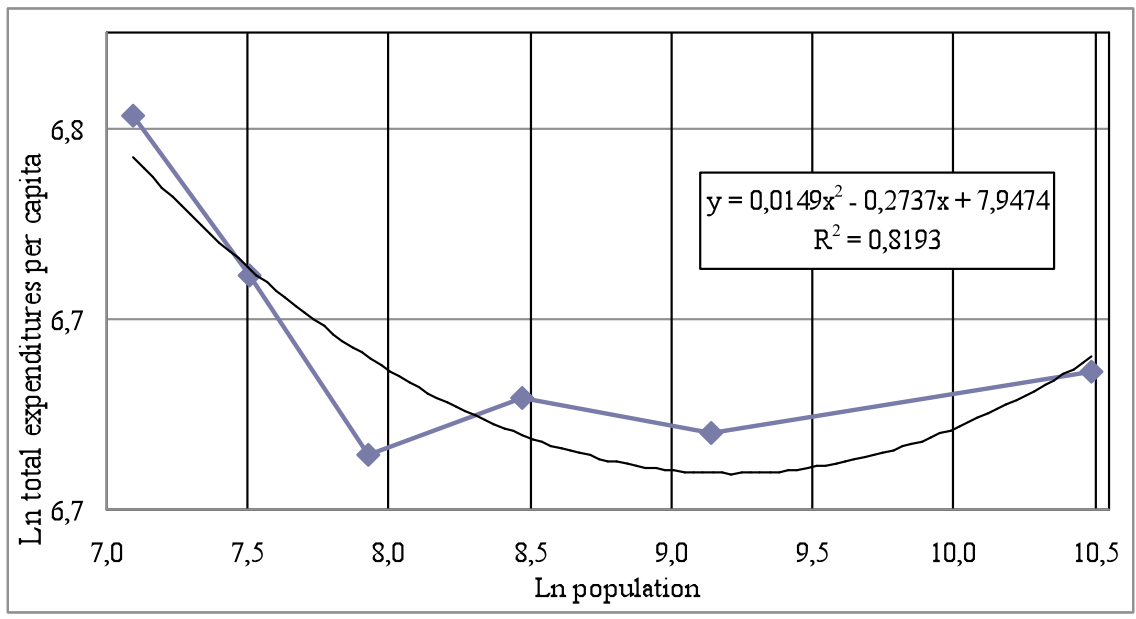

\section{Median Age}

Depending on the amount of local government social services aimed at the elderly, an aged population will have a positive impact on spending per capita. Several studies have proved this positive relationship. Gradstein and Kaganovich (2004) show that an aging population increases political pressure to adjust the composition of local government spending in favour of the old people. Di Matteo and Di Matteo (1998) show that the real per capita local government health expenditures are positively and significantly related to the proportion of the 
population aged 65 and over. However, the sign of the coefficient depends on the local government duties, i.e., if local governments must provide more services to children and young people than to the elderly, then a larger young population will imply more spending, and vice versa.

\section{Economic Level}

The literature, in general, indicates that the economic level has a positive influence on local government expenditures.

On the one hand, per capita income level within local government is another "classical variable" used by Fabricant (1952) to analyse the local government financial situation. On the other hand, Wagner's Law shows that income explains the government growth in the local authorities (Wagner, 1958). Thus, Bails and Tieslau (2000) show that the economic level is believed to impact local government expenditures. The theoretical argument is that the demand for public services is positively related to consumer income levels.

Abrams and Dougan (1986) find that a one-dollar increase in income raises combined state and local government spending per capita by 5-7 cents. Pettersson-Lidbom (2001) controls for the economic level because it is related to local government fiscal capacity, namely, most of the revenue comes from the proportional local income tax.

Bird (1970) shows that government-spending expansion is caused by an increase in per capita income. Dickson and Yu (1997) also show that local government spending is linked to an increase in per capita income. In the same way, Mitchell (1967), McEachern (1978), Kiewiet and Szalaky (1996) prove that per capita income has a positive influence on the level of local deficit. Furthermore, Farnham (1985) ascertains that the per capita income variable could pick up the influence of a positive income elasticity of demand for capital goods. In this case, its impact on expenditures would be positive. The economic level (measured by disposable family income) causes a higher demand for infrastructure and other kinds of expenditures (Hulten and Peterson, 1984). Finally, Groves et al. (1981), and Mercer and Gilbert (1996) also consider the per capita income variable as a good gauge of the municipal financial position.

Ashworth et al. (2005) argue that the economic level measured by a citizen's income shows an ambiguous influence on the local government fiscal situation. Regarding the demand indicator of public goods, if they are normal goods, the income will have a positive effect on public expenditures. Borge (1995) also supports this assumption, and the significant coefficient of private income indicates that Norwegian local public services on average are normal goods. Likewise, Allers et al. (2001) ascertain that the average household income is positively related to the local tax burden in the Netherlands. This result shows that municipal services are "normal". 


\section{Unemployment}

This variable measures the rate of citizens that demand certain social services. Inasmuch as local governments mainly provide unemployed services, the municipalities with a higher unemployment rate will spend more. Therefore, the variable coefficient depends on the municipal powers in unemployed services.

Bails and Tieslau (2000) ascertain that the higher the level of unemployment compensation, the higher the level of per capita local spending. Marlow and Shiers (1999) hypothesize that unemployment is positively related to crime rates because in the countries with relatively fewer jobs, there may be a greater incentive for criminal activity. This greater activity is connected with a higher per-capita expenditure on security.

Unemployment measures competition in the job market. Weak employment markets are expected to exert a negative influence on spending (Carruthers \& Ulfarsson, 2003 and 2008). In the same way, Holcombe and Williams (2008) also include the labour force percentage in order to control for the demographic characteristics of local governments. They report a negative relationship between the unemployment rate and the level of government expenditures.

\section{$3 \quad$ Local Governments in Spain}

There are three government levels in Spain: Central Government (Parliament and the Cabinet), Regional Governments (17), and local governments (50 provinces and 8,111 municipalities as of 1 January 2007). Municipalities are grouped by provinces, and the latter are grouped by Regional Governments.

Each municipality has a mayor, a cabinet, and a professional administration. The mayor is the head of the executive, and is indirectly elected by citizens. The citizens elect the members of the cabinet (aldermen) every four years, and they in turn elect the mayor. Municipalities are allowed to raise local taxes and charge tariffs for the services they provide.

The political parties at the national level in Spain also play their role in local governments. Thus, there are two main national parties at the local level: "Socialist Party" (left/progressive) and "Popular Party" (right/conservative). These two parties account for $80.84 \%$ out of the total number of aldermen in our sample. They are the most important parties at the local level.

Local governments have always played a crucial role in providing key services such as police, day-care nurseries, public transport, waste disposal, sewage, school maintenance, construction and management of sports centres and public green areas. 
Regarding the financial structure, local government funds come from the central government (grants) and from their own revenues. The own resources are local taxes, income from property and market activities, and user charges (which cannot exceed service costs). Local governments are entitled to set tax rates (within legal limits) and decide how to spend revenues by approving the budget within certain constraints. In 2001, a "Budgetary Stability Law" imposed limits on local government deficits. In accordance with this Law, Public Administrations will not be able to have a non-financial deficit (measured in accordance with the European System of Accounts -ESA methodology). This means that the non-financial revenues will have to cover at least the non-financial expenditures. Therefore, in practice, this imposes strong limitations on getting into debt.

\section{$4 \quad$ Methodology and Results}

\subsection{Sample}

Our sample is composed of all the Spanish municipalities with more than 1,000 inhabitants $(3,179$ local governments). The reason for eliminating the local governments with fewer than 1,000 inhabitants is twofold: the reliability of the financial data is doubtful for small local governments, and some variables were only available for local governments with more than 1,000 inhabitants. Our sample is among the largest ones used in urban sprawl studies (the sample size is similar to the recent work by Carruthers and Ulfarsson, 2008), and since we consider all the Spanish local governments with more than 1,000 inhabitants, the results are highly relevant. As Table 1 shows, other studies have worked with smaller samples.

According to Pettersson-Lidbom (2001) and Ashworth et al. (2005), municipal datasets have two main advantages over a cross-country study, namely, homogeneity and amplitude. First, heterogeneity (different legal structures and a socio-economic framework in cross-country samples) needs to be controlled (Blejer and Cheasty, 1991; Tellier, 2006). This feature is overcome at the municipal level within a country. Second, the dataset is considerably larger than cross-country studies. Finally, according to Poterba (1995), international comparisons of budget rules and public spending are problematic. The numerous non-budgetary differences between countries make it difficult to attribute differences in spending patterns only to fiscal institutions. Among other works that have also used sub-national data, we can point out: Borge (1995), Alt and Lowry (1994), Poterba (1994), Pettersson-Lidbom (2001), Ashworth et al. (2005) and Hagen and Vabo (2005).

\subsection{Variables}

Our model variables have been considered in agreement with the theoretical and empirical underpinnings. Furthermore, we have considered the control variables 
suggested by the literature. Expenditure variables have been calculated on a percapita basis to provide a comparison between local governments. All the data refer to 2005 , except for three variables: the 2001 population that was used to calculate population growth from 2001 to 2005 , and the 2001 population density and 2001 total expenditures, which are two instrumental variables in the regression. We have chosen 2005 for two reasons. First, it was the most recent available data when we wrote this study. Second, municipal elections took place in Spain in 2003 and 2007. Therefore, 2005 is expected to be free from the "municipal electoral cycle" bias. This cycle has been extensively investigated and reported in the literature, and it stems from the politicians' discretionary power over the public budget to increase their re-election chances. Thus, the pre-election year is influenced by the incumbents' strategy to increase spending in order to be re-elected, while fiscal adjustments take place in the post-election year.

We analyse three dependent variables (all of them per capita and in logs): total expenditures (Inexpendtoth_05), current operating expenditures (lnexpendcurrh_05), and investment expenditures (Ininvestmenth_05).

Our model considers seven independent variables (all expressed in logs, see Table 2 ) and a dummy variable for each Regional Government. Other works using a similar approach are, among others, Bodkin and Conklin (1971), and Holcombe and Williams (2008).

The literature shows that there is no agreement so far on the most appropriate measurement of urban sprawl. This is due to two factors: on the one hand, the absence of a consensus in the conceptualisation of sprawl; on the other hand, the problems that arise when quantifying urban sprawl. Therefore, researchers have used different approaches to the extent that some studies specifically address the measurement of sprawl (Galster et al., 2001; Torrens \& Alberti, 2000; Ewing, 1997; López \& Hynes, 2003). However, the most common indicator in the literature is population density, or some variations of it, because of its simplicity: Burchell et al., 1998; Gordon and Richardson, 1997; Torrens and Alberti, 2000; Cox and Utt, 2004; Carruthers and Ulfarsson, 2008; Holcombe and Williams, 2008. Even so, the use of population density has been criticised because although density may help to create economies of scale for certain urban services, it does not describe the unilateral character of urban areas (Carruthers, 2002), or because dense urban areas tend to have higher land values and thus generate more taxes (Ewing, 1997).

According to the aforementioned literature, we use the population density (lnpopdensurb_05) as an indicator of urban sprawl. Regarding the denominator, we do not consider all the municipal areas (in sq $\mathrm{km}$ ), but only urbanised areas (in sq $\mathrm{km}$ ), because it is a more accurate measurement of the population density. 
Along with this factor, we add other variables to check their influence on local government expenditures.

\section{Table 2:Definition of variables and descriptive statistic}

\begin{tabular}{|c|c|c|c|c|c|c|}
\hline \multicolumn{2}{|r|}{ Variable } & Description & Calculation & Mean(*) & Median(*) & St. dev. $(*)$ \\
\hline \multirow{3}{*}{ 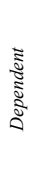 } & lnexpendtoth_05 & $\begin{array}{l}\text { Per capita total } \\
\text { expenditure in } 2005\end{array}$ & \multirow{3}{*}{ Taken from Spanish Ministry of Treasury } & 874.93 & 757.19 & $2,187.96$ \\
\hline & Inexpendcurrh_05 & $\begin{array}{l}\text { Per capita current } \\
\text { expenditure in } 2005\end{array}$ & & 588.76 & 536.00 & $1,383.56$ \\
\hline & Ininvestmenth_05 & $\begin{array}{l}\text { Investment expenditures } \\
\text { per capita in } 2005\end{array}$ & & 286.17 & 191.84 & 835.15 \\
\hline \multirow{8}{*}{ 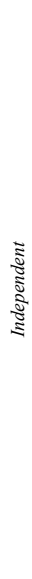 } & Ineconlevelh_05 & $\begin{array}{l}\text { Per capita income in } 2005 \\
\text { (economic level) }\end{array}$ & $\begin{array}{l}\text { Taken from "Lawrence R. Klein" } \\
\text { Institute for Economic Prediction }\end{array}$ & $12,006.29$ & $11,449.07$ & $2,679.81$ \\
\hline & In\%unemploy_05 & $\begin{array}{l}\text { Municipality population } \\
\text { unemployment rate in } \\
2005\end{array}$ & $\begin{array}{l}\text { Taken from the Spanish National } \\
\text { Statistics Institute }\end{array}$ & 0.04 & 0.04 & 0.02 \\
\hline & Inpopulation_05 & $\begin{array}{l}\text { Municipality population } \\
\text { in } 2005\end{array}$ & $\begin{array}{l}\text { Taken from the Spanish National } \\
\text { Statistics Institute }\end{array}$ & $13,237.03$ & $3,307.00$ & $72,451.51$ \\
\hline & Inpopdensurb_05 & $\begin{array}{l}\text { Municipality population } \\
\text { density in } 2005\end{array}$ & $\begin{array}{l}\text { Population_05/Urbanized km2. } \\
\text { Population taken from Spanish National } \\
\text { Statistics Institute. Urbanized km2 taken } \\
\text { from Property Assessment Office. }\end{array}$ & 8.540 & 8.630 & .770 \\
\hline & Inpopgrowth_01_05 & \multicolumn{2}{|c|}{ Population growth rate between 2001 and 2005} & 0.01 & 0.01 & 0.03 \\
\hline & lnmedianage_05 & \multicolumn{2}{|c|}{ Average age of population in 2005} & 41.69 & 41.18 & 4.53 \\
\hline & region & $\begin{array}{l}\text { Dummy variables for } \\
\text { each Spanish region }\end{array}$ & $\begin{array}{l}\text { Takes value } 1 \text { if the LG belongs to the } \\
\text { region. This makes a total of } 16(\mathrm{~N}-1) \\
\text { dummy variables ( } \mathrm{N}=17 \text { Spanish } \\
\text { regions). }\end{array}$ & & & \\
\hline & ln\%inschool_05 & $\begin{array}{l}\text { Percentage of } \\
\text { municipality population } \\
\text { attending school in } 2005\end{array}$ & $\begin{array}{l}\text { Sum of the population under } 15 \text { years of } \\
\text { age / population_05 }\end{array}$ & 0.14 & 0.14 & 0.03 \\
\hline \multirow{2}{*}{ 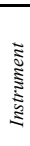 } & lnpopdensurb_01 & $\begin{array}{l}\text { Municipality population } \\
\text { density in } 2001\end{array}$ & $\begin{array}{l}\text { Population_01/Urbanized } \mathrm{km} 2 \text {. } \\
\text { Population taken from Spanish National } \\
\text { Statistics Institute. Urbanized km2 taken } \\
\text { from Property Assessment Office. }\end{array}$ & 8.625 & 8.705 & .792 \\
\hline & Intotexph_01_real & \multicolumn{2}{|c|}{ Per capita total expenditure in 2001 (real 2005 euros) } & 750.70 & 679.81 & 423.41 \\
\hline
\end{tabular}

\subsection{Model Specification}

The initial specification of the model corresponds to the following equation:

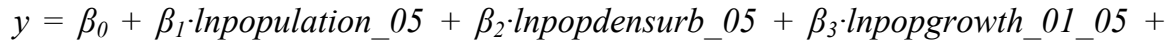

$\beta_{4} \cdot \ln \%$ unemploy_05 $+\beta_{5} \cdot$ lneconlevelh_05+ $\beta_{6} \cdot \operatorname{lnmedianage\_ 05}+$

$\beta_{7} \cdot$ ln\%inschool_05 $+\sum_{i=1}^{16} \alpha_{i} \cdot$ region $_{i}+\varepsilon$

for $\mathrm{y}=$ lnexpendtoth_05, lnexpendcurrh_05, lninvestmenth_05. 
We analyse two different approaches: Ordinary least squares regression (OLS) and two-stage regression (2SLS). The latter model uses two instruments to estimate 2005 population density. These two instrumental variables (both expressed in logs) are: 2001 total per capita government expenditures (in real 2005 euros), and 2001 population density (Holcombe and Williams, 2008, apply similar instruments):

$$
\begin{aligned}
& \text { lnpopdensurb_05 }=\pi_{0}+\pi_{1} \cdot \operatorname{lnpopdensurb\_ 01}+\pi_{2} \cdot \ln t o t e x p h \_01 \_r e a l+ \\
& \pi \cdot(\text { remaining regressors })+v
\end{aligned}
$$

2SLS is an appropriate procedure because authors like Holcombe and Williams (2008) suggest that there could be a direction of causality between population density and government expenditures. They think that higher government expenditures make the local government an attractive place to live, leading to an increase in population density. 2SLS allows us to control for this possible endogeneity.

After applying the Hausman (1978) with Davidson and Mc Kinnon (1993) auxiliary regression endogeneity test (see Table 3), we prove that there is a causality between population density and government expenditures in total spending and current spending regressions, while there is no causality in investment spending regression. Thus, 2SLS is an appropriate estimation of the two former regressions, while OLS is appropriate for the latter. Anyway, we present both estimations (2SLS and OLS) that present very similar results, confirming the robustness of our model.

At the outset, we considered both lnmedianage_05 and ln\%inschool_05 as independent variables as suggested by the literature (Holcombe and Williams, 2008). Nevertheless, these two variables present a high correlation in our sample: Pearson $=-.922$, significance $=.000$. Therefore, we eliminated ln\%inschool_05 in order to avoid multicollinearity problems.

Taking into account that our sample includes local governments of different sizes, it is likely that the observations are heteroskedastic, as assumed in the literature (Carruthers and Ulfarsson, 2008; Holcombe and Williams, 2008; Di Mateo, 1998). Accordingly, the model uses White's heteroskedasticity-consistent estimator for the variance-covariance matrix.

\subsection{Results}

Table 3 shows the estimation of the regressions as well as the tests applied. 
Table 3: Estimation in regressions

\begin{tabular}{|c|c|c|c|c|c|c|c|}
\hline & & \multicolumn{3}{|c|}{ Ordinary least squares regression model } & \multicolumn{3}{|c|}{ Two-stage least squares regression model } \\
\hline \multicolumn{2}{|c|}{ Dependent variable: } & lnexpendtoth_05 & Inexpendcurrh_05 & lninvestmenth_05 & Inexpendtoth_05 & lnexpendcurrh_05 & lninvestmenth_05 \\
\hline 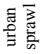 & Inpopdensurb_05 & $\begin{array}{r}* * *-.126 \\
(-7.951)\end{array}$ & $\begin{array}{r}* * *-.124 \\
(-8.463)\end{array}$ & $\begin{array}{r}* * *-.148 \\
(-5.252)\end{array}$ & $\begin{array}{r}* * *-148 \\
(-8.477)\end{array}$ & $\begin{array}{r}* * *-.152 \\
(-9.691)\end{array}$ & $\begin{array}{r}* * *-.159 \\
(-4.966)\end{array}$ \\
\hline \multirow{2}{*}{$\begin{array}{l}\mathscr{y} \\
\stackrel{0}{0}\end{array}$} & Ineconlevelh_05 & $\begin{array}{r}* * * .266 \\
(5.298)\end{array}$ & $\begin{array}{r}* * .328 \\
(7.614)\end{array}$ & $\begin{array}{r}.057 \\
(.551)\end{array}$ & $\begin{array}{r}* * * .248 \\
(4.921)\end{array}$ & $\begin{array}{r}* * * .310 \\
(7.225)\end{array}$ & $\begin{array}{r}.039 \\
(.366)\end{array}$ \\
\hline & In\%unemploy_05 & $\begin{array}{r}* * *-.082 \\
(-3.292)\end{array}$ & $\begin{array}{r}-.012 \\
(-.536)\end{array}$ & $\begin{array}{r}* * *-.249 \\
(-5.137)\end{array}$ & $\begin{array}{r}* * *-.079 \\
(-3.108)\end{array}$ & $\begin{array}{r}-.009 \\
(-.429)\end{array}$ & $\begin{array}{r}* * *-.245 \\
(-4.958)\end{array}$ \\
\hline \multirow{6}{*}{ 嵒 } & Inpopulation_05 & $\begin{array}{r}-.008 \\
(-1.015)\end{array}$ & $\begin{array}{r}* * * .050 \\
(6.794)\end{array}$ & $\begin{array}{r}* * *-.127 \\
(-7.096)\end{array}$ & $\begin{array}{r}-.004 \\
(-.409)\end{array}$ & $\begin{array}{r}* * * .057 \\
(7.357)\end{array}$ & $\begin{array}{r}* * *-.125 \\
(-6.611)\end{array}$ \\
\hline & Inpopgrowth_01_05 & $\begin{array}{r}* * * .058 \\
(6.229)\end{array}$ & $\begin{array}{r}* * * .062 \\
(7.305)\end{array}$ & $\begin{array}{l}* * .038 \\
(2.106)\end{array}$ & $\begin{array}{r}* * * .057 \\
(5.701)\end{array}$ & $\begin{array}{r}* * * .059 \\
(6.582)\end{array}$ & $\begin{array}{l}* * .040 \\
(2.130)\end{array}$ \\
\hline & Inmedianage_05 & $\begin{array}{r}* * *-.365 \\
(-2.605)\end{array}$ & $\begin{array}{r}-.175 \\
(-1.392)\end{array}$ & $\begin{array}{r}* * *-.879 \\
(-3.374)\end{array}$ & $\begin{array}{r}* * *-.377 \\
(-2.611)\end{array}$ & $\begin{array}{r}-.176 \\
(-1.356)\end{array}$ & $\begin{array}{r}* * *-.921 \\
(-3.463)\end{array}$ \\
\hline & region & Yes & Yes & Yes & Yes & Yes & Yes \\
\hline & $\mathrm{N}$ & 3,179 & 3,179 & 3,179 & 3,179 & 3,179 & 3,179 \\
\hline & Endogeneity test ${ }^{*}$ & 2.451 & 3.939 & .350 & & & \\
\hline \multicolumn{8}{|c|}{$\begin{array}{l}\text { All the equations include an intercept. T-values in parentheses. Significance: } * * * 1 \%,{ }^{*} 5 \%,{ }^{*} 10 \\
\text { lntotexph_01_real. } \\
\text { " Hausman (1978) with Davidson and Mc Kinnon (1993) auxiliary regression endogeneity test. } \\
\text { White's heteroskedasticity-consistent standard errors \& covariance in both models. }\end{array}$} \\
\hline
\end{tabular}

\section{$5 \quad$ Discussion}

\section{$5.1 \quad$ Urban Sprawl}

The coefficient of the variable lnpopdensurb_05 in the three categories of expenditures per capita (lnexpendtoth_05, lnexpendcurr_05 and lninvestmenth_05) shows a clear and significant pattern in both 2SLS and OLS: the higher the population density, the lower the expenditures per capita. This evidence confirms the previous literature such as Carruthers and Ulfarsson (2003, 2008), Burchell and Mukherji (2003), Cox and Utt (2004), and Litman (2004). Thus, our empirical analysis proves that the municipalities with urban development according to smart growth achieve spending savings. According to the size of the coefficients, the savings stemming from the high population density are achieved mainly in local government investment spending. This result is similar to Holcombe and Williams (2008) who show that higher population density is associated with lower infrastructure expenditures per capita. We agree with these authors in the sense that one of the arguments against urban sprawl is that higher density can reduce expenditures on infrastructure. Burchell et al. (1998), Snyder and Bird (1998), and Livingstone et al. (2003) find a similar result: urban sprawl is assumed to be costly in terms of public infrastructure. 


\subsection{Economic Factors}

As expected, the increase in economic level (Ineconlevelh_05) is connected with higher expenditures per capita in all the categories. Our results are in line with the literature: Abrams and Dougan (1986), Dickson and Yu (1997). According to Borge (1995) and Ashworth et al. (2005), the economic level, as an indicator of public-goods demand if these are 'normal goods,' will have a positive effect on public expenditures. Our results make it clear that at the municipal level in Spain, public goods are 'normal goods'.

The unemployment rate (In\%unemploy_05) is also relevant in order to explain municipal spending. We have ascertained that the relationship between the unemployment rate and municipal spending per capita is negative in all categories. Some previous works (Carruthers \& Ulfarsson, 2003 \& 2008; Holcombe \& Williams, 2008) also found the same relationship. Unemployment services are not a municipal duty in Spain (this is a duty of the Regional and Central Government). Therefore, since unemployed people demand fewer public services that require user charges (sports, culture, etc.), the relationship is negative.

\subsection{Social Factors}

Regarding population (Inpopulation_05), it has a negative impact on total expenditures and investment, while the effect is positive on current expenditures. Regarding investment spending, Shapiro (1963) concludes that economies of scale yield a U-shaped function, being 250,000 inhabitants the point where the curve gets a positive slope. Since only 16 local governments out of 3,179 have population over 250,000 inhabitants in our sample, our data are placed in the negative part of the Shapiro function (see Figure 1).

The population growth (Inpopgrowth_01_05) has a positive and significant influence on all the categories of expenditure per capita. This means that, from the point of minimum spending per capita (see Figure 1), when population keeps on growing, the spending per capita rises.

Our data show that population age has a negative influence on per-capita municipal spending. Accordingly, our data suggest that local governments provide more services to children and young people than to the elderly. Thus, the aged population leads to less spending.

\section{Conclusions}

This paper evaluates the impact of population density (urban sprawl) on municipal expenditures. We contribute one of the most representative samples used so far: 
3,179 Spanish municipalities for the year 2005 to the European literature (most research focuses on US).

We find an influence of urban sprawl on spending because the higher the population density, the lower the expenditures (total, current and investment) per capita. This result supports the claims in favour of smart growth in urban areas.

In relation to the economic level, our results are in line with the literature: higher economic level means higher municipal expenditures per capita. This result indicates that municipal public goods are 'normal goods'.

Concerning social factors, population has a negative impact on investment, while there is a positive effect on current expenditures. The population growth has a positive and significant influence on all expenditure categories. Considering both results together, the data suggest economies of scale to a limit. From this limit, an increase in population leads to higher per capita spending. In other words, from the point of minimum per capita spending, if population keeps growing, per capita spending rises.

\section{References}

Abrams, B. A. \& Dougan, W. R. (1986) The effects of constitutional restraints on governmental spending, Public Choice, 49 (2), pp. 101-116.

Allers, M., De Haan, J. \& Sterks, C. (2001) Partisan influence on the local tax burden in the Netherlands, Public Choice, 106(3-4), pp. 351-363.

Ashworth, J., Geys, B. \& Heyndels, B. (2005) Government Weakness and Local Public Debt Development in Flemish Municipalities, International Tax and Public Finance, 12(4), pp. 395422.

Bails, D. \& Tieslau, M. A. (2000) The impact of fiscal constitutions on state and local expenditures, Cato Journal, 20(2), pp. 255-277.

Bird, R. M. (1970) The Growth of Government Spending in Canada, Canadian Tax Papers, No. 51, July.

Blejer, M. I. \& Cheasty, A. (1991) The Measurement of Fiscal Deficits: Analytical and Methodological Sigues, Journal of Economic Literature, 29(4), pp. 1644-1678.

Bodkin, R. G. \& Conklin, D. W. (1971) Scale and other determinants of municipal government expenditures in Ontario: A quantitative analysis, International Economic Review, 12(3), pp. 465-481.

Borge, L. (1995) Economic and political determinants of fee income in Norwegian local governments, Public Choice, 83(3-4), pp. 353-373.

Bruegmann, R. (2005) Sprawl: A Compact History (Chicago, IL: University of Chicago Press).

Burchell, R. (1992) Impact Assessment of the New Jersey Interim State Development and Redevelopment Plan (Trenton, NJ: New Jersey Office of State Planning).

Burchell, R. \& Mukhjerji, S. (2003) Conventional Development versus Managed Growth: The Costs of Sprawl, American Journal of Public Health, 93(9), pp. 1534-1540.

Burchell, R., Listokin, D. \& Galley, C. (2000) Smart Growth: More Than a Ghost of Urban Policy Past, Less Than a Bold New Horizon, Housing Policy Debate, 11(4), pp. 821-879. 
Burchell, R., Lowenstein, G., Dolphin, W. R., Galley, C. C., Downs, A., Seskin, S., Still, K. G. \& Moore, T. (2002) Costs of Sprawl - 2000, Transportation Cooperative Research Program Report 74 (Washington, DC: National Academy Press).

Burchell, R., Shad, N. A., Listokin, D., Phillips, H., Downs, A., Seskin, S., Davis, J. S., Moore, T., Helton, D. \& Gall, M. (1998) The Costs of Sprawl. Revisited, Transportation Cooperative Research Program Report 39 (Washington, DC: National Academy Press).

Burchfield, M., Overman, H.G., Puga, D. \& Turner, M. A. (2006) Causes of sprawl: A portrait from space, Quarterly Journal of Economics, 121(2), pp. 587-633.

Carruthers, J. I. (2002) The impacts of state growth management programmes: a comparative analysis, Urban Studies, 39(11), pp.1956-1982.

Carruthers, J. I. \& Ulfarsson, G. F. (2003) Urban sprawl and the cost of public services, Environment and Planning B: Planning and Design, 30(4), pp. 503-522.

Carruthers, J. I. \& Ulfarsson, G. F. (2008) Does Smart Growth Matter to Public Finance?, Urban Studies, 45 (9), pp. 1791-1820.

Cox, W. \& Utt, J. (2004) The Costs of Sprawl Reconsidered: What the Data Really Show, Backgrounder, No. 1770.

Dajani, J.S. (1973) Cost Studies of Urban Public Services, Land Economics, 49(4), pp. 479-483.

Di Matteo, L. \& Di Matteo, R. (1998) Evidence on the determinants of Canadian provincial government health expenditures: 1965-1991, Journal of Health Economics, 17(2), pp. 211-228.

Davidson, R. \& MacKinnon, J. G. (1993) Estimation and Inference in Econometrics (New York: Oxford University Press).

Dickson, V. \& Yu, W. (1997) Spending by Canadian Provincial Governments: an Empirical Analysis, Public Finance, 52(2), pp. 145-160.

Downing, P. B. (1969) The economics of urban sewage disposal (New York: Praeger).

Elis-Williams, D. G. (1987) The Effect of Spatial Population Distribution on the Cost of Delivering Local Services, Journal of the Royal Statistical Society, 150(2), pp. 152-166.

Ewing, R. (1997) Is Los Angeles-style sprawl desirable?, Journal of the American Planning Association, 63(1), pp. 107-126.

Fabricant, S. (1952) The trend of government activity in the United States since 1900 (New York: National Bureau of Economic Research).

Farnham, P. G. (1985) Re-examining Local Debt Limits: A Disaggregated Analysis, Southern Economic Journal, 51(4), pp. 1186-1201.

Galster, G., Hanson, R., Ratcliffe, M. \& Wolman, H. (2001) Wrestling sprawl to the ground: defining and measuring an elusive concept, Housing Policy Debate, 12(4), pp. 681-717.

Glaeser, E. L. \& Kahn, M. E. (2004) 'Sprawl and Urban Growth', In: Henderson, J. V. \& Thisse, J. F. (ed.) Handbook of Regional and Urban Economics (Amsterdam: North-Holland), pp. 2498-2527.

Gordon, P. \& Richardson, H. W. (1997) Are Compact Cities a Desirable Planning Goal?, Journal of the American Planning Association, 63(1), pp. 95-106.

Gradstein, M. \& Kaganovich, M. (2004) Aging population and education finance, Journal of Public Economics, 88(12), pp. 2469-2485.

Groves, S. M., Godsey, W. M. \& Shulman, M. A. (1981) Financial Indicators for Local Governments, Public Budgeting and Finance, 1(2), pp. 5-19.

Hagen, T. P. \& Vabo, S. I. (2005) Political characteristics, institutional procedures and fiscal performance: Panel data analyses of Norwegian local governments, 1991-1998, European Journal of Political Research, 44(1), 43-64.

Hausman, J. A. (1978) Specification Tests in Econometrics', Econometrica, 46(6), pp. 1251-1271.

Hempel, G. H. (1973) Quantitative Borrower Characteristics Associated with Defaults on Municipal General Obligation, Journal of Finance, 28(2), pp. 523-530. 


\section{LEX LOCALIS - JOURNAL OF LOCAL SELF-GOVERNMENT B. Benito, F. Bastida \& M. D. Guillamón: Urban Sprawl and the Cost of Public Services: An Evaluation of Spanich Local Governments}

Hess, G. R., Daley, S. S., Dennison, B. K., McGuinn, R.P., Morin, V. Z., Shelton, W. G., Lubkin, S. R., Potter, S. M., Savage, R. E., Snow, C. M. \& Wrege, B. M. (2001) Just what is sprawl, anyway?, Carolina Planning, 26(2), pp. 11-26.

Holcombe, R. G. \& Williams, D. (2008) The Impact of Population Density on Municipal Government Expenditures, Public Finance Review, 36(3), pp. 359-372.

Hulten, C. R. \& Peterson, G. E. (1984) Is the United States Underinvesting in Public Capital? The Public Capital Stock: Needs, Trends and Performance, American Economic Review, 74 (2), pp. 166-173.

Kiewiet, R. \& Szalaky, K. (1996) Constitutional limitations on borrowing: An analysis of state bonded indebtedness, Journal of Law, Economics and Organization, 12(1), pp. 62-97.

Knaap, G. (2003) Talking Smart in the United States', In Haccoû, H. A. \& Middleton, D. (eds.) Quest for Partners in Research on Multifunctional and Intensive Land Use (Gouda: Habiforum).

Knaap, G., Talen, E., Olshansky, R. \& Forrest, C. (2000) Government Policy and Urban Sprawl (Illinois: Department of Natural Resources).

Ladd H. F. \& Yinger J. (1991) America's Ailing Cities: Fiscal Health and the Design of Urban Policy (Baltimore, MD: Johns Hopkins University Press).

Ladd, H. F. (1992) Population Growth, Density and the Costs of Providing Services, Urban Studies, 29(2), pp. 273-295.

Ladd, H. F. (1994) Fiscal impacts of local population growth: A conceptual and empirical analysis, Regional Science and Urban Economics, 24(6), pp. 661-686.

Litman, T. (2003) Evaluating Criticism of Smart Growth (Victoria, BC, Canada: Victoria Transport Policy Institute).

Litman,T. (2004) Evaluating Transportation Land Use Impacts (Victoria, BC, Canada: Victoria Transport Policy Institute).

Livingston, M., Shawb, W. W. \& Harris, L. K. (2003) A model for assessing wildlife babitats in urban landscapes of eastern Pima County (Arizona (USA): Landscape and Urban Planning).

López, R. \& Hynes, H. P. (2003) Sprawl in the 1990s: Measurement, distribution, and trends, Urban Affairs Review, 38(3), pp. 325-355.

Marlow, M. L. \& Shiers, A. F. (1999) Do law enforcement expenditures crowd-out public education expenditures?, Applied Economics, 31(2), pp. 255-266.

McEachern, W. A. (1978) Collective Decision Rules and Local Debt Choice: A Test of the Median-Voter Hypothesis, National Tax Journal, 31(2), pp. 129-136.

McElfish, J. (2007) Ten Things Wrong with Sprawl (Washington, DC: Environmental Law Institute Report).

McGuire, T. J. \& Sjoquist, D. L. (2002) Urban Sprawl and the Finances of State and Local Governments, in D.L. Sjoquist (ed.) State and Local Finances under Pressure (London: Edward Elgar).

Mercer, T. \& Gilbert, M. (1996) A Financial Condition Index for Nova Scotia Municipalities', Government Finance Review, 12(5), pp. 36-38.

Mitchell, W. E. (1967) The Effectiveness of Debt Limit on State and Local Government Borrowing. The Bulletin, No. 45 (New York: New York University, Graduate School of Business Administration).

Nechyba, T. J. \& Walsh, R. P. (2004) Urban sprawl, Journal of Economic Perspectives, 18(4), pp. 177-200.

Pettersson-Lidbom, P. (2001) An empirical investigation of the strategic use of debt, The Journal of Political Economy, 109(3), pp. 570-583.

Poterba, J. M. (1994) State responses to fiscal crises: The effects of budgetary institutions and politics, The Journal of Political Economy, 102(4), pp. 799-823.

Poterba, J. M. (1995) Capital budgets, borrowing rules, and state capital spending, Journal of Public Economics, 56(2), pp. 165-187. 
RERC (1974) The Costs of Sprawl: Environmental and Economic Costs of Alternative Residential Development Patterns at the Urban Fringe, Real Estate Research Corporation (Washington, DC: US Environmental Protection Agency).

Rivers, M. J. \& Yates, B. M. (1997) City Size and Geographic Segmentation in the Municipal Bond Market, The Quarterly Review of Economics and Finance, 37(3), pp. 633-645.

Schmandt, H. J. \& Stephens, G. R. (1963) Local Government Expenditure Patterns in the United States, Land Economics, 39(4), pp. 397-406.

Shapiro, H. (1963) Economies of Scale and Local Government Finance, Land Economics, 39(2), pp. 175-186.

Snyder, K. \& Bird, L. (1998) Paying the Costs of Sprawl: Using Fair-Share Costing to Control Sprawl (Washington, DC: U.S. Department of Energy).

Song, Y. \& Zenou, Y. (2006) Property tax and urban sprawl: Theory and implications for US cities, Journal of Urban Economics, 60(3), pp. 519-534.

Tellier, G. (2006) Public expenditures in Canadian provinces: An empirical study of politicoeconomic interactions, Public Choice, 126(3-4), pp. 367-385.

Tiebout, C.M. (1960) Economies of Scale and Metropolitan Governments, The Review of Economies and Statistics, 42(4), pp. 442-444.

Torrens, P. \& Alberti, M. (2000) Measuring Sprawl, Working Paper Series No. 27, (London: Centre for Advanced Spatial Analysis, University College London).

Wagner, A. (1958) Three extracts on public finance, In: Musgrave, R. \& Peacock, A. T. (eds.) Classics in the Theory of Public Finance, pp. 1-16 (London: Macmillan).

Whitney, C. \& Gordon, J. (2001) An Investigation of Sprawl Development and Its Effect On Transportation Planning: The Lower Savannah Region of Government (Orangenburg: South Carolina State University).

\section{Acknowledgements}

We acknowledge the financial support of the Fundación Séneca, Regional Government of Murcia - Spain (05785/PHCS/07) and of the Ministry of Science and Innovation (SEJ 2007$67441 / \mathrm{ECON})$. 